\title{
Decompressive Craniotomy in the Treatment of Malignant Ischemic Stroke of Cerebral Hemispheres (Review)
}

\author{
DOI: $10.17691 / \mathrm{stm} 2016.8 .3 .17$ \\ Received April 26, 2015
}

A.V. Yarikov, Neurosurgeon ${ }^{1}$; PhD Student²;

A.N. Lavrenyuk, Head of the $1^{\text {st }}$ Neurosurgery Department ${ }^{1} ;$ PhD Student ${ }^{3}$;

A.V. Balyabin, MD, PhD, Researcher ${ }^{3}$; Neurosurgeon ${ }^{1}$

${ }^{1}$ City Clinical Hospital No.39, Moskovskoe shosse, 144, Nizhny Novgorod, 603028, Russian Federation;

${ }^{2}$ Nizhny Novgorod State Medical Academy, 10/1 Minin and Pozharsky Square, Nizhny Novgorod, 603005,

Russian Federation;

${ }^{3}$ Privolzhsky Federal Research Medical Center, Ministry of Health of the Russian Federation,

18 Verkhne-Volzhskaya naberezhnaya St., Nizhny Novgorod, 603155, Russian Federation

\begin{abstract}
The authors have considered the capabilities of decompressive craniotomy in malignant ischemic stroke treatment. Malignant stroke is understood to be stroke with extensive cerebral ischemia, post-ischemic edema formation, and the presence of lateral and/or axial cerebral displacement that is mainly due to proximal middle cerebral artery occlusion. There were highlighted the etiology and pathogenesis of this type of cerebrovascular disease. The disease predictors (clinical, radiological, laboratory) were described in detail, the most significant among them being emphasized. Based on randomized multicenter studies the researchers determined the indications, contraindications and selection criteria of patients when this surgical approach is used to treat malignant ischemic stroke. Surgical approach was demonstrated to enable to reduce case mortality, and improve functional treatment outcomes and results. There were described in detail the technique and peculiarities of decompressive craniotomy in this pathology, as well as the main postoperative complications. The authors considered the problem of optimal surgery time, and suggested an original treatment algorithm for patients with this pathology.
\end{abstract} HAMLET.

Key words: malignant ischemic stroke; cerebral decompression; hemicraniectomy; cerebral edema; NIHSS scale; DESTINY II;

Cerebrovascular diseases are still one of major medical and social problems of the contemporary world. In Russia, per year 400-450 thousand new cases of acute cerebrovascular disease (ACVD) are recorded [19], and worldwide over 7 million of ACVD are registered [10]. The mortality from strokes in developed countries ranks third among other diseases [2, 5, 10-14]. Ischemic strokes (IS) account for $70-85 \%$ of all ACVD [2, 3, $5,10,13,15,16]$. About $31 \%$ patients after IS require continuous support, and $20 \%$ patients are not able to move by themselves $[1,3,4,6]$. Only nearly $20 \%$ patients, who survived IS are able to return to previous job $[1,4,6]$.

There is a special category of ACVD patients with the so called malignant ischemic stroke (MIS), which occurs in $10-15 \%$ cases [17-25]. MIS is understood as stroke with an extensive cerebral ischemic area with post-ischemic edema and lateral and/or axial brain dislocation [22, 25, 26]. MIS is usually related to the occluded proximal pat of medial cerebral artery (MCA) causing infarction in the area of over $50 \%$ of its blood supply [26, 27]. More frequently, MIS develops in young patients due to the absence of atrophy and lower brain tolerance. Patients with malignant course of the disease were found to be 10 years younger on the average than those with an ordinary IS course [18]. The mortality rate in MIS patients is 70-80\%, and disability among survived patients is $80 \%[17-21,23,24,26,28-34]$. Fatality in such patients is related to progressive brain edema, uncontrolled increase in intracranial pressure (ICP) and dislocated midbrain structures [24, 25, 34-37].

\section{Malignant ischemic stroke pathogenesis}

Blocked blood and oxygen entry the brain through a thrombosed vessel results in severe pathophysiological and pathobiochemical changes. Aerobic glycolysis is impaired leading to the glucose metabolism switch to an anaerobic process and, subsequently, resulting in lactate acidosis and accumulation of calcium ions. In turn, it is followed by the impaired functioning of ionic pumps, and chloride and sodium ions enter cells promoting cytotoxic edema development [1]. Edematous brain tissue causes local ICP. When local pressure is higher than the resistance of the surrounding brain matter, cerebral dislocation develops (Figure 1). Dislocation causes the displacement of midbrain structures resulting first to the compression of veins and local venous hypertension

For contacts: Anton V. Yarikov, e-mail: anton-yarikov@mail.ru 

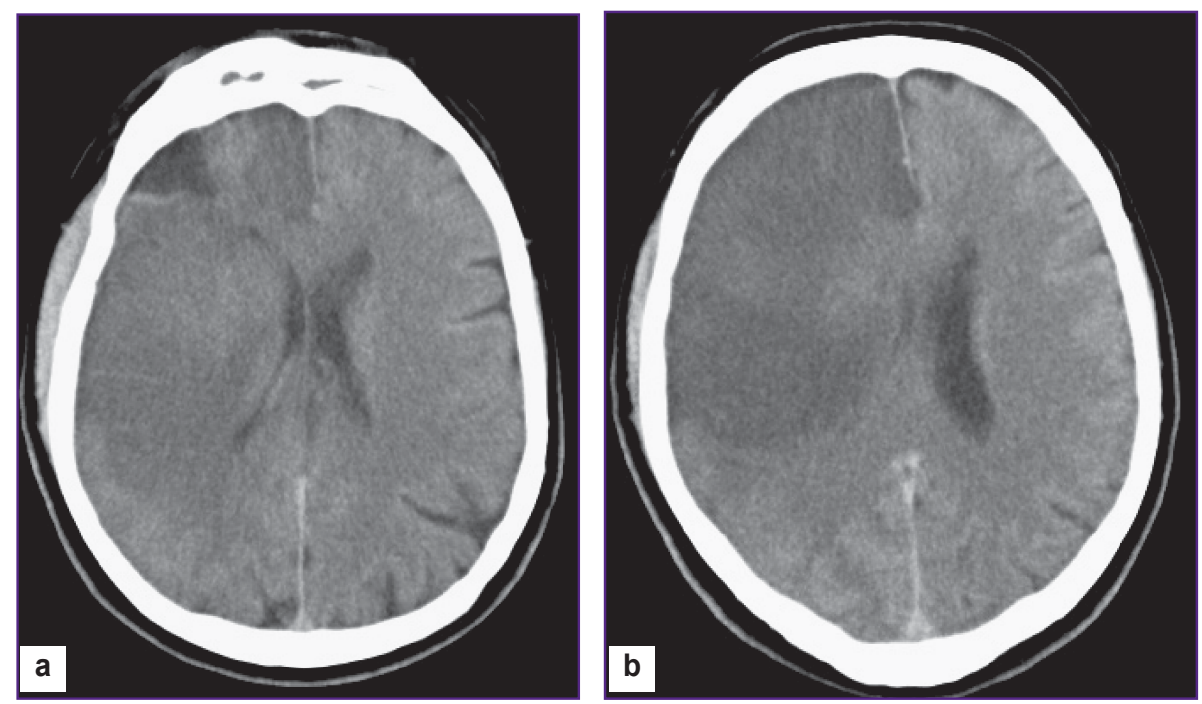

Figure 1. Brain CT: Patient Z. with malignant ischemic stroke: (a) $7 \mathrm{~h}$ after the onset of the disease, midbrain structures are not dislocated; (b) $32 \mathrm{~h}$ after the disease onset, midbrain structures are dislocated by $7 \mathrm{~mm}$ to the right, negative changes

rise, and then to an additional local volume increase and obstruction of cerebrospinal fluid pathways resulting in sharp increase of ICP. Subsequently, it leads to artery compression and decreased perfusion of cerebral tissue, and not only in the infarction area. All that contributes to the infarction zone growth and progressive pathological process on a vicious circle principle [5, $26,38]$. Other satellite reactions are the following: impaired microvascular tone, edema of endothelial cells, activation of platelets, leukocytes and blood coagulation system [18]. Transtentorial herniation is the major reason for lethality in MIS. Case fatality within the first $48 \mathrm{~h}$ of the disease in such patients reaches $47 \%$, and within $49-96 \mathrm{~h}$ the number increases $34 \%$, i.e. total mortality in transtentorial herniation is $81 \%$ [26].

\section{Prognostic factors of malignant ischemic stroke}

Some authors have revealed direct relationship between ICP increase and the following transtentorial herniation development [29], moreover, brain dislocation develops earlier, if ICP rise is significant that accounts for patients' physical condition aggravation [17]. Rapid augmentation of neurological signs, impaired consciousness level, a gaze deviation due to stroke, hemiplegia within the first $6 \mathrm{~h}$ after the disease onset combined with occluded proximal MCA are unfavorable prognostic factors [26].

Proved predictors of failure are the following: hypodensity of over $50 \%$ brain matter in MCA circulation, ischemic focus volume is over $145 \mathrm{~cm}^{3}$, lateral dislocation of midbrain structures is over $7-10 \mathrm{~mm}$, the presence of axial dislocation of II and over degree according to Kornienko, hypodensity in frontal and parietal lobes is over $70 \%$, and in temporal lobe it is over $80 \%$, development of asymmetric obstructive hydrocephaly, reduced convexital cerebrospinal fluid space, smoothed cortical sulci, deformed lateral ventricles, compression of basal cisterns, cerebral perfusion is reduced by over $66 \%$, the absence of agent accumulation in positron emission tomography in the area with volume of over $160 \mathrm{~cm}^{3}$ [18, 24, 26, 27, 29, 35, 39, 40-42].

Protein level of astrogliae $\mathrm{S} 100 \mathrm{~B}$, which is released from cells after their death, is potentially useful laboratory technique for MIS diagnosis [26]. In stroke this protein specific for nervous tissue enters the blood reaching its maximum concentration level on days $2-4$, and its amount depends on ischemic area extent. Infarction area volume is related to S100B level. The blood serum protein $24 \mathrm{~h}$ after the onset of the disease is $1.03 \mu \mathrm{g} / \mathrm{L}$, and coupled with sensitivity $(94 \%)$ and specificity $(84 \%)$ can be a sign of massive cerebral edema [18]. Unfortunately, currently, the diagnostic technique is not available in any hospital, and its reliability in prognosis should be proved by larger studies.

Serena et al. [43] undertook a study to determine the concentration of molecular markers of blood-brain barrier (BBB) break in MIS patients. Within the first $24 \mathrm{~h}$ after the disease onset in blood plasma of patients they measured the levels of glutamate, TNF-alpha, glycine, IL-10, GABA, IL-6, matrix metalloproteinase-9 (MMP-9) and cell fibronectin (c-Fn). The patients with malignant ischemic stroke were found to have twofold MMP-9, and c-Fn level six times as high compared to the control group. The authors showed c-Fn level in serum equal $16.6 \mathrm{mg} / \mathrm{ml}$ (norm is $0.4 \mathrm{mg} / \mathrm{ml}$ ) to be MIS predictor, the sensitivity being $90 \%$ and specificity about $100 \%$.

Thus, astroglial protein S100B $(>0.4 \mu \mathrm{g} / \mathrm{L}$, norm $<0.105 \mu \mathrm{g} / \mathrm{L})$, matrix metalloproteinase-9 $(>140 \mathrm{ng} / \mathrm{mL}$, norm $<25 \mathrm{ng} / \mathrm{mL}$ ) and cell fibronectin ( $\geqslant 16.6 \mathrm{mg} / \mathrm{ml}$, norm $0.4 \mathrm{mg} / \mathrm{ml}$ ) can serve as molecular MIS markers.

\section{Malignant ischemic stroke therapy}

The position of decompressive craniotomy in malignant ischemic stroke therapy. In 1905 Cushing proposed a technique for decompressive craniotomy (DC) as a palliative technique in the treatment of brain tumors by reducing intracranial hypertension. First decompressive hemicranionectomies in MIS were performed in 1930s [44, 45]. 


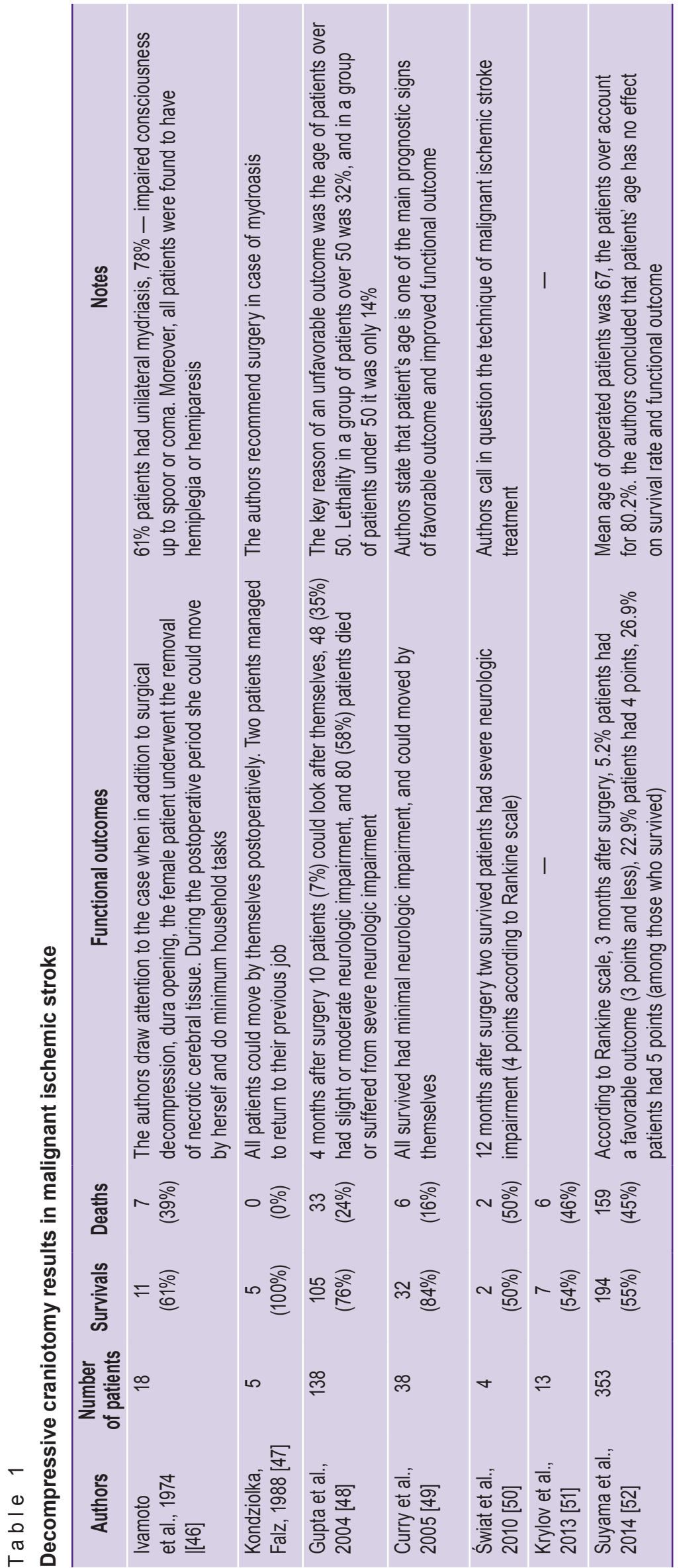

Table 1 shows in detail the results obtained using the technique [46-52].

Further, there were carried out a great number of studies comparing the results of surgical and conservative treatment of MIS. Many studies have shown the advantage of surgical management of the pathology. Table 2 demonstrates all research findings comparing surgical and conservative treatment [53-59].

The problem of optimal surgery time in patients with the pathology is still unstudied. Some surgeons suggest an operation at an ultra-early stage, before edema and cerebral dislocation develop, while others prefer a delayed surgery, when edema and brain dislocation develop. Table 3 represents the findings of researches determining favorable surgery time (ultraearly or delayed) [60, 61].

There are a number of animal studies proving DC efficiency in MIS [62-66].

Thus, according to the majority of studies, when DC is performed in patients with MIS, the lethality reduces significantly, and functional outcomes improve, especially in young patients $[22,23,28,32-34,39$, 67-82].

Enrollment criteria of patients. An advisory protocol of stroke patient management published in 2008 specifies the following criteria for patients to be enrolled in a group to perform DC:

1) age 18-60;

2) MCA infarction signs on CT $50 \%$ or more, or $>145 \mathrm{~cm}^{3}$ according to diffuse weighed MRI;

3) neurological status according to NIHSS is > 15 score;

4) depression of consciousness by 1 point and more according to 1 a level of NIHSS (corresponds to the level "clouding of consciousness" and lower);

5) a surgery not later than $48 \mathrm{~h}$ since the onset of the disease.

One of the main success factors of MIS surgical treatment is a surgery time. Operative therapy should be preventive and ahead of the dislocation syndrome $[18,29]$. A surgery cannot resuscitate "dead" neurons. It is preferable to perform an operation within the first $48 \mathrm{~h}$ since the onset of the disease [18, 32, 40, 75], however, the efficiency is possible in case a patient is operated within 96-hour period [17]. An ultra-early surgery (within the first $6 \mathrm{~h}$ after symptoms appear) produces the 


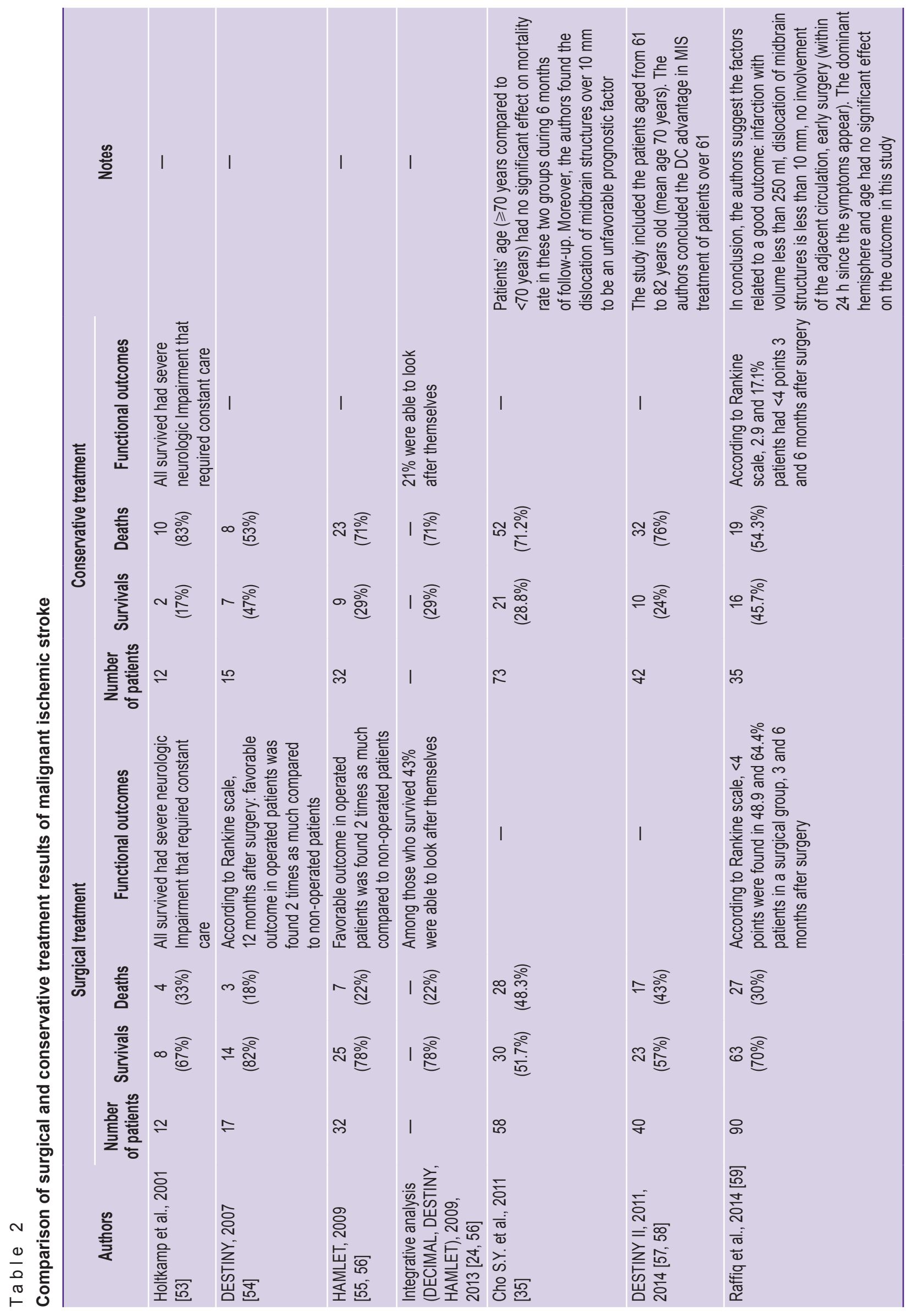


Table 3

Comparison of surgical (ultra-early and delayed) treatment results of malignant ischemic stroke

\begin{tabular}{|c|c|c|c|c|c|c|c|c|c|}
\hline \multirow[b]{2}{*}{ Authors } & \multicolumn{4}{|c|}{ Ultra-early surgery } & \multicolumn{4}{|c|}{ Delayed operative intervention } & \multirow[b]{2}{*}{ Notes } \\
\hline & $\begin{array}{l}\text { Number } \\
\text { of patients }\end{array}$ & Survivals & Deaths & $\begin{array}{c}\text { Functional } \\
\text { outcomes }\end{array}$ & $\begin{array}{l}\text { Number } \\
\text { of patients }\end{array}$ & Survivals & Deaths & $\begin{array}{l}\text { Functional } \\
\text { outcomes }\end{array}$ & \\
\hline $\begin{array}{l}\text { Schwab S. } \\
\text { et al., } 1998 \\
{[60]}\end{array}$ & $\begin{array}{l}31 \text { (on average, } \\
\text { surgery was } \\
\text { performed } 21 \mathrm{~h} \\
\text { since the onset } \\
\text { of the disease) }\end{array}$ & $\begin{array}{c}26 \\
(84 \%)\end{array}$ & $\begin{array}{c}5 \\
(16 \%)\end{array}$ & - & $\begin{array}{l}31 \text { (on average, } \\
\text { surgery was } \\
\text { performed } 39 \mathrm{~h} \\
\text { since the onset } \\
\text { of the disease) }\end{array}$ & $\begin{array}{c}24 \\
(76 \%)\end{array}$ & $\begin{array}{c}8 \\
(34 \%)\end{array}$ & - & $\begin{array}{l}\text { The stay in the intensive } \\
\text { care unit after an ultra- } \\
\text { early surgery averaged } \\
7.4 \text { days, while } \\
\text { in delayed surgery } \\
\text { it was } 13.3 \text { days }\end{array}$ \\
\hline $\begin{array}{l}\text { Cho D.Y. } \\
\text { et al., } 2003 \\
\text { [61] }\end{array}$ & $\begin{array}{l}12 \text { (within } 6 \mathrm{~h} \\
\text { after symptoms } \\
\text { appeared) }\end{array}$ & $\begin{array}{c}11 \\
(92.7 \%)\end{array}$ & $\begin{array}{c}1 \\
(8.3 \%)\end{array}$ & - & - & $\begin{array}{c}- \\
(63.3 \%)\end{array}$ & $(36.7 \%)$ & - & - \\
\hline
\end{tabular}

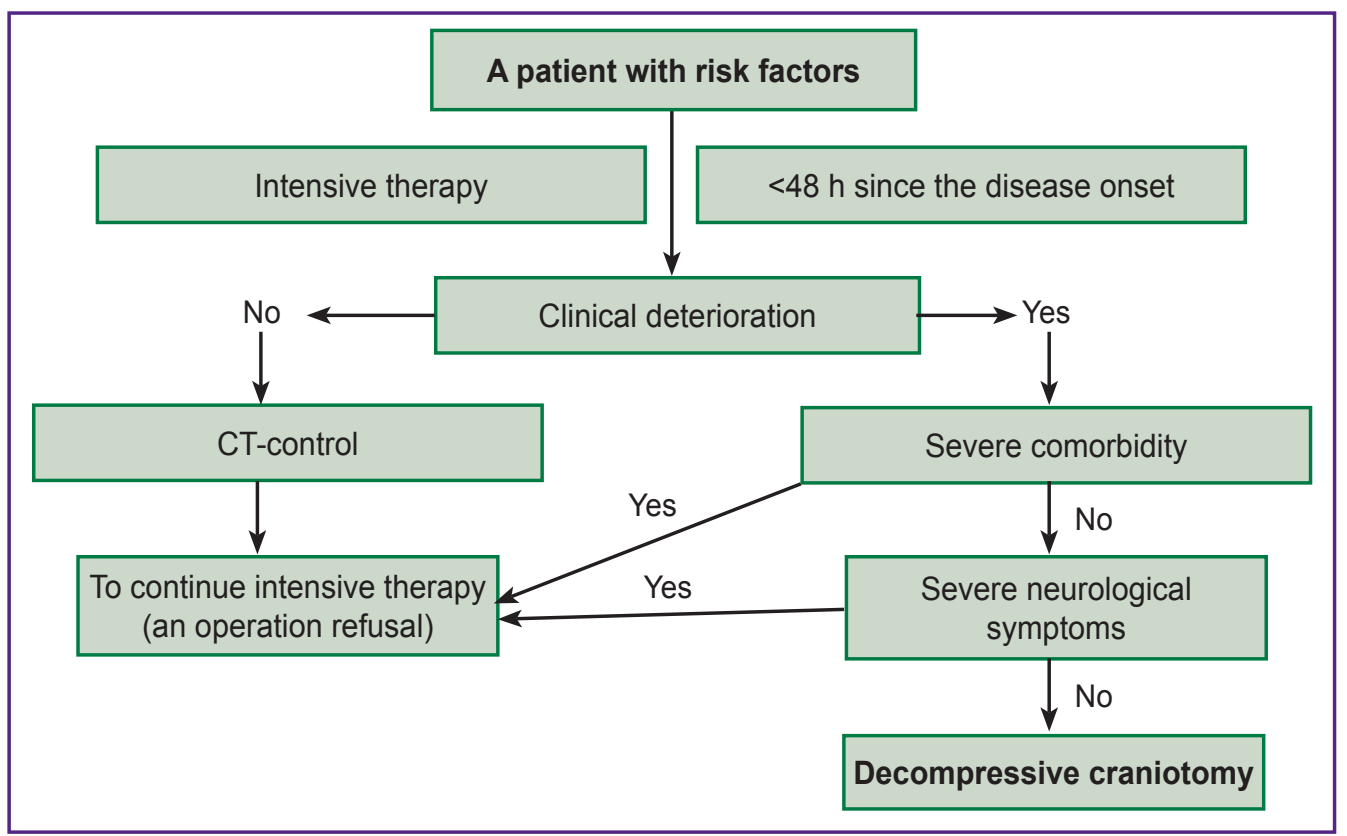

Figure 2. The selection scheme of patients for decompressive craniotomy in malignant ischemic stroke

greater effect [61]. Therefore, all patients with MIS and the disease period less than $48 \mathrm{~h}$ should be examined by a surgeon to assess the operative treatment capabilities [18]. The age of 18-60 years is prognostically more favorable, but the efficiency of surgical treatment has been also proved in patients over $60[19,52,84]$. The dislocation of midbrain structures by over $7-10 \mathrm{~mm}$ is a surgical indication as well $[19,27,75]$. After systemic fibrinolysis, an operative treatment is also effective and does not differ in long-term postoperative functional outcomes [85]. DC is recommended in unilateral mydriasis or progressive consciousness level reduction [26].

$D C$ is inadvisable if stroke is beyond MCA circulation, the disease duration is over $48 \mathrm{~h}$, and the consciousness level is up to deep coma (less than 6 points) with bilateral mydriasis, in continuous stem symptoms, systemic blood disorders and severe somatic comorbidities [17, 18, $26,32,40]$. The question of performing DC in MIS is to be decided in each specific case based on the wish of a patient or his family, as well as considering possible functional outcomes. Patient's age and comorbidity presence are of importance when choosing surgery as a primary operative treatment. The model of MIS patients' selection for DC looks as follows (Figure 2).

Operative technique. The operative intervention consists in the resection of a fronto-parieto-temporal fragment, opening and free flap plasty of dura mater [17, 26]. Trephine window should be not less than $12 \mathrm{~cm}$ in diameter, since the smaller size results in brain matter entrapment that reduces the survival rate from 80 to $55 \%$ [86]. So, in prospective studies (DESTINY I, DECIMAL, 
HAMLET) the size of trephine window is not less than $12 \mathrm{~cm}$ in diameter.

The study by Chung [87] has demonstrated the maximal decompression size (over 14-16 $\mathrm{cm}$ in diameter, or over $399 \mathrm{~cm}^{2}$ ) compared to a large size $\left(12 \mathrm{~cm}\right.$ or $\left.308 \mathrm{~cm}^{2}\right)$ to increase the percentage of a successful outcome (according to Rankine scale <3) 3 months after stroke and reduce the number of poor results and postoperative lethality.

One of the skin incision types in DC is the incision of soft tissues in fronto-parieto-temporal region in the form of "a question mark" with the base situated near the tragus (Figure 3).

Another incision type is an incision in the form of a large "horseshoe" (Figure 4). This incision type is smaller, causes less bleeding, and enables to preserve the main trunks of superficial temporal artery, and soft tissue stage of the surgery takes less time [29].

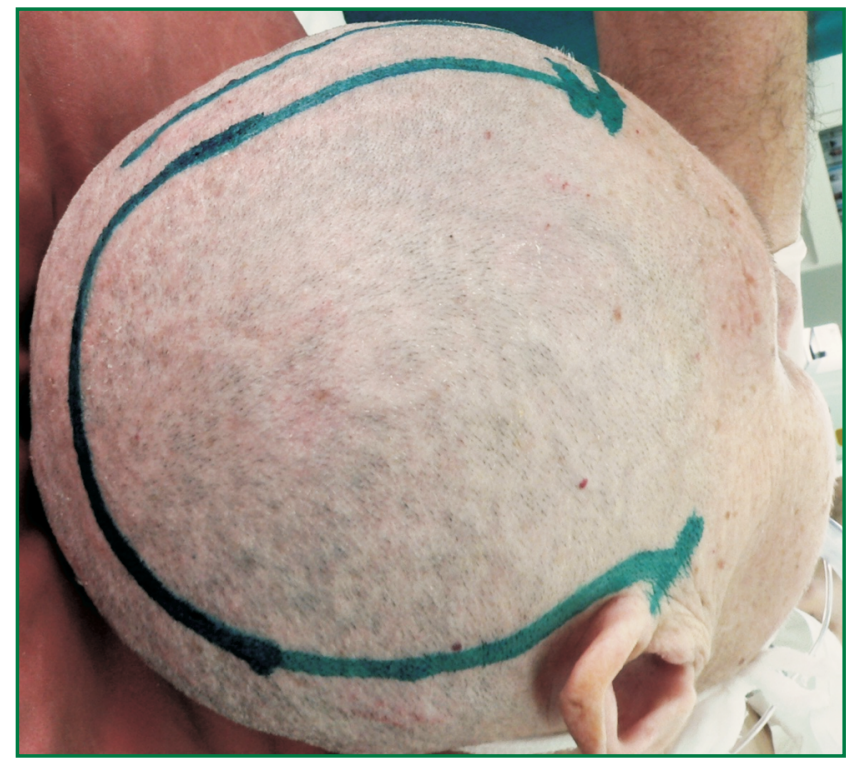

Figure 3. The incision of soft tissues in fronto-parietotemporal region in the form of "a question mark"
The bone resection borders are the following: anterior (frontal) - along the pupillary line; posterior $-4 \mathrm{~cm}$ posteriorly from the external acoustic meatus; upper up to the level of the superior sagittal sinus; lower the bottom of middle cranial fossa (Figure 5). It is of primary importance to resect temporal squamosa in the basal direction, since at this level pacchionian foramen is located, where the brain stem is trapped in temporotentorial dislocation $[17,26,88]$.

Craniotomy is followed by arciform incision of dura mater along the bone window perimeter, with it suturing to the periosteum for the purpose of epidural hematoma prevention [17, 26, 88]. Ischemic cerebral tissue is not resected $[17,26]$. Further, free duraplasty is performed using a graft (synthetic, as a rule), which is fixed in several points at the top of the wound to prevent the transplant dislocation. Soft tissues should be sutured in layers and particularly carefully to provide

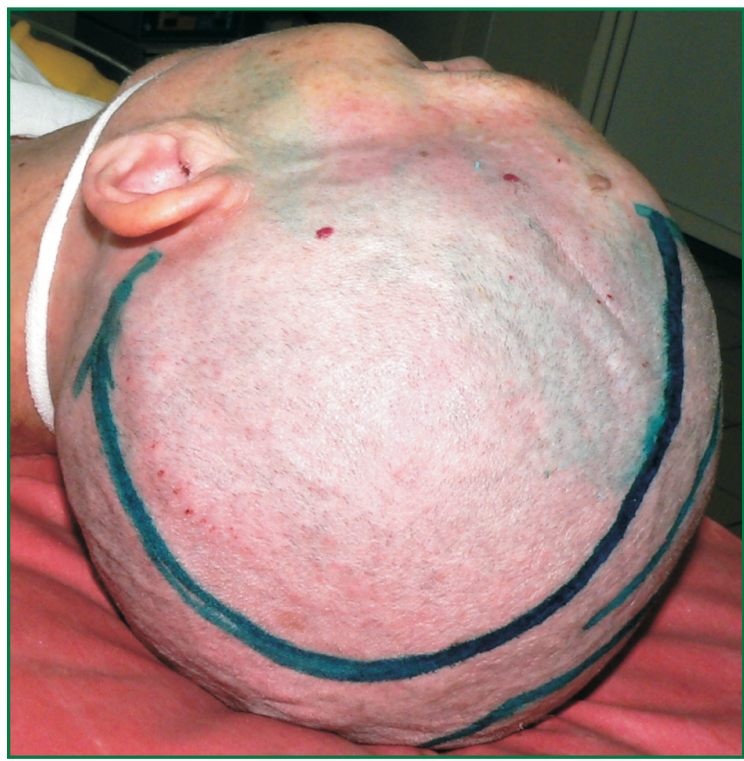

Figure 4. Malacotomy in the form of a large "horseshow"

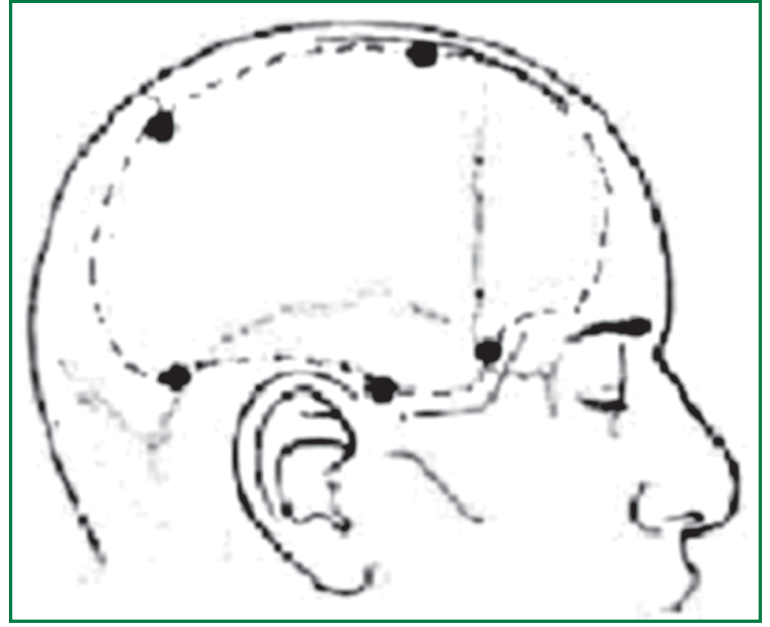

Рис. 5. Границы резекции кости при выполнении декомпрессивной трепанации черепа отмечены прерывистой линией 
wound integrity and prevent postoperative wound liquorrhea [17]. Some researchers combine DC and uncoparahippocampectomy, partial lobectomy, removal of necrotic brain matter and ICP sensor installation [26, 29, 49].

The most optimal time for subsequent cranioplasty is $1.5-6$ months after DC $[17,18,89]$. In addition, the number of complications reaches $26 \%$ : epileptic attacks $15.6 \%$, superficial wound infections $3.1 \%$, hydrocephaly $3.1 \%$, transient neurological impairments $3.1 \%$, and osteomyelitis $2.1 \%$ [90]. Wachter et al. [91] reported the complication rate in $30 \%$ cases: $17.4 \%$ - aseptic osteonecrosis, $5 \%$ - wound infections, $2.5 \%$ hematomas, $2.7 \%$ - hygromas, and $1.7 \%$ - poor cosmetic results.

The effect of decompressive craniotomy on treatment outcomes. Many authors have reported DC to have higher efficiency in MIS than that in severe craniocerebral injuries $[69,92]$. It is related to the fact that the prolapse of cerebral matter in trephining defect is less due to decreased arterial inflow and less mass-effect due to unilateral impairment, whereas craniocerebral trauma is accompanied by diffuse cerebral edema [13]. MIS patients after DC are found to have ICP reduction, improved cerebral hemodynamics proved by CT-perfusion findings [29, 68, 93-96].

Unfavorable factors for cerebral hemodynamics are the following: surgery performed more than $48 \mathrm{~h}$ after the disease onset, over $10 \mathrm{~mm}$ displacement of midbrain structures, and patient's age over 55 [68]. Currently, there are no eloquent evidences on ICP monitoring required in patients after $D C[29,97]$.

Unfavorable outcome factors in DC in MIS patients are considered to be the following ones: over $10 \mathrm{~mm}$ displacement of midbrain structures, age over 60, anisocoria, impaired consciousness level up to coma. In a number of cases, the factor is the infarction of all the blood supply territory of the internal carotid artery [29]. The effect of the anterior and posterior cerebral arteries involved in the infarction on the disease outcome has not yet been proved in operated patients.

The main DC complications in MIS are the following: postoperative epidural hematoma, meningitis, wound infection, parenchymatous brain injury, liquorrhea, hygroma, hemorrhagic conversion of the infarction zone, cosmetic defects [24, 89, 98]. All these complications deteriorate MIC course and prognosis, and in some cases can determine the severity of an underlying disease. So, a bone flap removal in the postoperative period results in trephined skull syndrome or "sunken skin flap" syndrome that causes the loss of life quality, cosmetic defects and disability percentage increase [99].

The main causes of death of such patients are the following: pneumonia, deep venous thrombosis of lower extremities, thromboembolia of the pulmonary artery, sepsis, multiple-organ-failure syndrome [89, 100].

\section{Conclusion}

The analysis of DC results in MIS enable to make convincing findings of reduced case mortality and improved functional outcomes in DC that offers an opportunity to advise the technique to be used in certain patients. This applies especially the patients under 60 , who can be operated on early (less than $48 \mathrm{~h}$ since the onset of the disease), however, the death rate and severe disability have been determined to reduce among older patients. When performing DC, a correct technique of the surgery is of great concern: a trephine window being not less than $12 \mathrm{~cm}$, resection of basal areas of the temporal bone, wide opening of dura followed by free flap plasty. Moreover, there should be kept in mind that the surgery itself bears a certain risk of complications: infectious, hemorrhagic, cosmetic.

The subject requires further investigations, which should be aimed at revealing MIS predictors, subsequent correction of indications and surgical contraindications, and determination of optimal time and volume of the operation.

Study Funding and Conflicts of Interest. The study was not funded by any sources, and the authors have no conflicts of interest related to the present study.

\section{References}

1. Gusev E.I., Martynov M.Yu., Kamtchatnov P.R. Ischemic stroke: current status. Doktor.Ru 2013; 5(83): 7-12.

2. Nevrologiya. Natsional'noe rukovodstvo [Neurology. National guidelines]. Pod. red. Guseva E.I., Konovalova A.N., Skvortsovoy V.I., Gekht A.B. [Gusev E.I., Konovalov A.N., Skvortsova V.I., Gekht A.B. (editors)]. Moscow: GEOTARMedia; 2009; $1040 \mathrm{p}$.

3. Muraveva V.N., Karpova E.N. Modern concepts of risk factors and prevention of stroke (literature review). Mezhdunarodnyy zhurnal eksperimental'nogo obrazovaniya 2014; 3(part 2): 59-64.

4. Shiryaeva E.A., Federko N.L. Follow-up care and early rehabilitation of patients after acute ischemic stroke conditions in the sanatorium "Pearl". Zdorov'e. Meditsinskaya ekologiya. Nauka 2011; 45(2): 16-18.

5. Mongush H.D., Ondar A.B., Chylbakool R.C. Medical care for patients with stroke at stages of ambulance. Sibirskiy meditsinskiy zhurnal (Irkutsk) 2013; 118(3): 81-84.

6. Teshen A.N. Morbidity cerebral stroke analysis in the Kursk region. Zhurnal nauchnykh statey Zdorov'e i obrazovanie vXXI veke 2010; 12(3): 356.

7. Suslina Z.A., Chechetkin A.O., Kuntsevich G.I., Krotenkova M.V. Application algorithm of carotid angio-imaging techniques. Nervnye bolezni 2013; 1: 6-9.

8. Akhmedov A.D., Usachev D.lu., Lukshin V.A., Shmigel'skiI A.V., Beliaev A.lu., Sosnin A.D. Carotid endarterectomy in patients with high surgical risk. Voprosy neyrokhirurgii im. N.N. Burdenko 2013; 4: 36-42.

9. Kadykov A.S., Shakhparonova N.V. Early rehabilitation of patients after stroke. The role of drug therapy. Nervnye bolezni 2014; 1: 22-25.

10. Mykhaylov V.B. Nonpsychotic psychotic disorders on 
cerebral stroke patients. Ukrai'ns'kyj visnyk psyhonevrologii' 2011; 1(66): 72-78.

11. Kruchkova O.N., Turna E.U. Management of patients with ischemic stroke. Krymskiy terapevticheskiy zhurnal 2011; 1(16): 20-25.

12. Prekina V.I., Samolkina O.G. Ischemic stroke and heart rate variability. Sovremennye problemy nauki i obrazovaniya 2014; 5: 443.

13. Kulikov A.Yu., Komarov I.A. Pharmacoeconomical assessment of cerebrolisin in the treatment of the acute disturbances of cerebral circulation. Sovremennaya farmakoekonomika i farmakoepidemiologiya 2013; 6(4): 38-45.

14. Kernan W.N., Ovbiagele B., Black H.R., Bravata D.M., Chimowitz M.I., Ezekowitz M.D., Fang M.C., Fisher M., Furie K.L., Heck D.V., Johnston S.C., Kasner S.E., Kittner S.J., Mitchell P.H., Rich M.W., Richardson D., Schwamm L.H., Wilson J.A.; American Heart Association Stroke Council, Council on Cardiovascular and Stroke Nursing, Council on Clinical Cardiology, and Council on Peripheral Vascular Disease. Guidelines for the prevention of stroke in patients with stroke and transient ischemic attack: a guideline for healthcare professionals from the American Heart Association/American Stroke Association. Stroke 2014; 45(7): 2160-2236, http:// dx.doi.org/10.1161/STR.0000000000000024.

15. Neverovsky D.V. Smoking and ischemic stroke. Nevrologiya, neyropsikhiatriya, psikhosomatika 2010; 4: 42-47.

16. Kuzovlev O.P., Afonina N.S. Structurally-resonant electro- and electromagnetic therapy in treatment of patients with ischemic stroke. Klinicheskaya praktika 2011; 3(7): 15-19.

17. Dashjan V.G., Talypov A.E. Decompressive craniotomy in the treatment of ischemic strokes of cerebral hemispheres. Neyrokhirurgiya 2011; 4: 8-15.

18. Ronchetti G., Panciani P.P., Stefini R., Spena G., Fontanella M.M. Acute supratentorial ischemic stroke: when surgery is mandatory. Biomed Res Int 2014; 2014: 624126, http://dx.doi.org/10.1155/2014/624126.

19. Yu J.W., Choi J.H., Kim D.H., Cha J.K., Huh J.T. Outcome following decompressive craniectomy for malignant middle cerebral artery infarction in patients older than 70 years old. J Cerebrovasc Endovasc Neurosurg 2012; 14(2): 65-74, http://dx.doi.org/10.7461/jcen.2012.14.2.65.

20. Wang D.Z., Nair D.S., Talkad A.V. Acute decompressive hemicraniectomy to control high intracranial pressure in patients with malignant MCA ischemic strokes. Curr Treat Options Cardiovasc Med 2011; 13(3): 225-232, http://dx.doi. org/10.1007/s11936-011-0121-1.

21. Rabadán A.T., Sposato L., Mazia C. Update on interventional treatment of acute ischemic stroke. Medicina ( $B$ Aires) 2010; 70(5): 463-468.

22. Taylor B., Appelboom G., Connolly E.S. Jr. Age selection for decompressive craniectomy in malignant middle cerebral artery infarction. World Neurosurg 2015; 83(3): 301302, http://dx.doi.org/10.1016/j.wneu.2014.05.012.

23. Winston K.R., Beauchamp K.M. Letter to the editor: decompression for ischemia. J Neurosurg 2013; 118(6): 13821383, http://dx.doi.org/10.3171/2012.11.JNS121653.

24. Flechsenhar J., Woitzik J., Zweckberger K., Amiri H., Hacke W., Jüttler E. Hemicraniectomy in the management of space-occupying ischemic stroke. J Clin Neurosci 2013; 20(1): 6-12, http://dx.doi.org/10.1016/j.jocn.2012.02.019.

25. Gautschi O.P., Cadosch D., Stienen M.N., Steiner L.A.,
Schaller K. Decompressive craniectomy in acute stroke the different perspective. Anasthesiol Intensivmed Notfallmed Schmerzther 2012; 47(1): 8-13, http://dx.doi. org/10.1055/s-0032-1301374.

26. Dzhindzhikhadze R.S., Dreval' O.N., Lazarev V.A. Decompressive hemicraniectomy in extensive ischemic middle cerebral artery stroke. Voprosy neyrokhirurgii im. N.N. Burdenko 2012; 76(3): 69-74.

27. Burov S.A., Nikitin A.S., Asratian S.A., Krylov V.V. Risk factors for malignant course of massive ischemic stroke. Neyrokhirurgiya 2012; 3: 18-25.

28. Godoy D., Piñero G., Cruz-Flores S., Alcalá Cerra G., Rabinstein A. Malignant hemispheric infarction of the middle cerebral artery. Diagnostic considerations and treatment options. Neurologia 2016; 31(5): 332-343, http://dx.doi. org/10.1016/j.nrl.2013.02.009.

29. Burov S.A., Nikitin A.S. Possibilities of decompressive craniotomy for treatment of patients with malignant forms of massive ischemic stroke. Neyrokhirurgiya 2011; 3: 82-87.

30. Giossi A., Volonghi I., Del Zotto E., Costa P., Padovani A., Pezzini A. Large middle cerebral artery and panhemispheric infarction. Front Neurol Neurosci 2012; 30: 154-157, http://dx.doi.org/10.1159/000333628.

31. Vibbert M., Mayer S.A. Early decompressive hemicraniectomy following malignant ischemic stroke: the crucial role of timing. Curr Neurol Neurosci Rep 2010; 10(1): 1-3, http://dx.doi.org/10.1007/s11910-009-0081-y.

32. Merenda A., DeGeorgia M. Craniectomy for acute ischemic stroke: how to apply the data to the bedside. Curr Opin Neurol 2010; 23(1): 5-58, http://dx.doi.org/10.1097/ WCO.0b013e328334bdf4.

33. Hwang D.Y., Matouk C.C., Sheth K.N. Management of the malignant middle cerebral artery syndrome. Semin Neurol 2013; 33(5): 448-455, http://dx.doi. org/10.1055/s-0033-1364211.

34. Subramaniam S., Hill M.D. Decompressive hemicraniectomy for malignant middle cerebral artery infarction: an update. Neurologist 2009; 15(4): 178-184, http:// dx.doi.org/10.1097/NRL.0b013e3181963d19.

35. Cho S.Y., Oh C.W., Bae H.J., Han M.K., Park H., Bang J.S. The prognostic factors that influence longterm survival in acute large cerebral infarction. J Korean Neurosurg Soc 2011; 49(2): 92-96, http://dx.doi.org/10.3340/ jkns.2011.49.2.92.

36. van der Worp H.B., Kappelle L.J. Early decompressive hemicraniectomy in older patients with nondominant hemispheric infarction does not improve outcome. Stroke 2011; 42(3): 845-846, http://dx.doi.org/10.1161/ STROKEAHA.110.603605.

37. Jeon S.B., Koh Y., Choi H.A., Lee K. Critical care for patients with massive ischemic stroke. J Stroke 2014; 16(3): 146-160, http://dx.doi.org/10.5853/jos.2014.16.3.146.

38. Schwab S. Treatment of malignant MCA infarction. Zhurnal Grodnenskogo gosudarstvennogo meditsinskogo universiteta 2010; 3(31): 3-8.

39. Mostofi K. Neurosurgical management of massive cerebellar infarct outcome in 53 patients. Surg Neurol Int 2013; 4: 28, http://dx.doi.org/10.4103/2152-7806.107906.

40. Wartenberg K.E. Malignant middle cerebral artery infarction. Curr Opin Crit Care 2012; 18(2): 152-163, http:// dx.doi.org/10.1097/MCC.0b013e32835075c5.

41. Dohmen C., Galldiks N., Bosche B., Kracht L., Graf R. The severity of ischemia determines and predicts malignant 
brain edema in patients with large middle cerebral artery infarction. Cerebrovasc Dis 2012; 33(1): 1-7, http://dx.doi. org/10.1159/000330648.

42. Thomalla G., Hartmann F., Juettler E., Singer O.C., Lehnhardt F.G., Köhrmann M., Kersten J.F., Krützelmann A., Humpich M.C., Sobesky J., Gerloff C., Villringer A., Fiehler J., Neumann-Haefelin T., Schellinger P.D., Röther J.; Clinical Trial Net of the German Competence Network Stroke. Prediction of malignant middle cerebral artery infarction by magnetic resonance imaging within 6 hours of symptom onset: a prospective multicenter observational study. Ann Neurol 2010; 68(4): 435-445, http://dx.doi.org/10.1002/ana.22125.

43. Serena J., Blanco M., Castellanos M., Silva Y., Vivancos J., Moro M.A., Leira R., Lizasoain I., Castillo J., Dávalos $A$. The prediction of malignant cerebral infarction by molecular brain barrier disruption markers. Stroke 2005; 36(9): 1921-1926.

44. Brown M.M. Surgical decompression of patients with large middle cerebral artery infarcts is effective: not proven. Stroke 2003; 34(9): 2305-2306, http://dx.doi.org/10.1161/01. str.0000089298.19012.9b.

45. Kim A.V., Antonov G.I., Lazarev V.A., Dzhindzhikhadze R.S., Miklashevich E.R., Mel'nichuk S.V., Gladyshev S.Ju., Kurnosenko V.Ju. The surgical treatment of patients with ischemic stroke within the territory of middle cerebral artery in acute period. Neyrokhirurgiya 2014; 1: 126-131.

46. Ivamoto H.S., Numoto M., Donaghy R.M. Surgical decompression for cerebral and cerebellar infarcts. Stroke 1974; 5(3): 365-370, http://dx.doi.org/10.1161/01.str.5.3.365.

47. Kondziolka D., Fazl M. Functional recovery after decompressive craniectomy for cerebral infarction. Neurosurgery 1988; 23(2): 143-147, http://dx.doi. org/10.1227/00006123-198808000-00002.

48. Gupta R., Connolly E.S., Mayer S., Elkind M.S. Hemicraniectomy for massive middle cerebral artery territory infarction: a systematic review. Stroke 2004; 35(2): 539-543, http://dx.doi.org/10.1161/01.str.0000109772.64650.18.

49. Curry W.T. Jr., Sethi M.K., Ogilvy C.S., Carter B.S. Factors associated with outcome after hemicraniectomy for large middle cerebral artery territory infarction. Neurosurgery 2005; 56(4): 681-692, http://dx.doi.org/10.1227/01. neu.0000156604.41886.62.

50. Świat M., Targosz-Gajniak M., Arkuszewski M., Pięta M., Gamrot J., Wojtacha M., Bażowski P., Opala G. Decompressive hemicraniectomy in ischaemic stroke. Neurol Neurochir Pol 2010; 44(2): 131-138, http://dx.doi.org/10.1016/ s0028-3843(14)60004-9.

51. Krylov V.V., Nikitin A.S., Burov S.A., Petrikov S.S., Asratian S.A., Averin A.lu., Kol'iak E.V. Decompressive craniotomy in the complex intensive treatment of malignant forms of massive ischemic stroke. Zhurnal nevrologii i psikhiatrii im. S. S. Korsakova 2013; 113(1): 15-22.

52. Suyama K., Horie N., Hayashi K., Nagata I. Nationwide survey of decompressive hemicraniectomy for malignant middle cerebral artery infarction in Japan. World Neurosurg 2014; 82(6): 1158-1163, http://dx.doi.org/10.1016/j.wneu. 2014.07.015.

53. Holtkamp M., Buchheim K., Unterberg A., Hoffmann O., Schielke E., Weber J.R., Masuhr F. Hemicraniectomy in elderly patients with space occupying media infarction: improved survival but poor functional outcome. J Neurol Neurosurg Psychiatry 2001; 70(2): 226-228, http://dx.doi.org/10.1136/ jnnp.70.2.226.
54. Jüttler E., Schwab S., Schmiedek P., Unterberg A., Hennerici M., Woitzik J., Witte S., Jenetzky E., Hacke W.; DESTINY Study Group. Decompressive surgery for the treatment of malignant infarction of the middle cerebral artery (DESTINY): a randomized, controlled trial. Stroke 2007; 38(9): 2518-2525, http://dx.doi.org/10.1161/strokeaha.107.485649.

55. Hofmeijer J., Kappelle L.J., Algra A., Amelink G.J., van Gijn J., van der Worp H.B.; HAMLET investigators. Surgical decompression for space-occupying cerebral infarction (the hemicraniectomy after middle cerebral artery infarction with life-threatening edema trial [HAMLET]): a multicentre, open, randomised trial. Lancet Neurol 2009; 8(4): 326-333, http:// dx.doi.org/10.1016/S1474-4422(09)70047-X.

56. Mitchell P., Gregson B.A., Crossman J., Gerber C., Jenkins A., Nicholson C., Todd N.V., Ross N., Bhattathiri P., Nissen J., Crawford P.J., Wynne-Jones G., Sengupta R.P., Graham L., Gani A., Davis M., Gray C., Barer D., Dorman P., Millar D., Williamson J., Durham H., Jones A., Hastie H., Mendelow A.D. Reassessment of the HAMLET study. Lancet Neurol 2009; 8(7): 602-604, http://dx.doi.org/10.1016/S14744422(09)70157-7.

57. Jüttler E., Unterberg A., Woitzik J., Bösel J., Amiri H., Sakowitz O.W., Gondan M., Schiller P., Limprecht R., Luntz S., Schneider H., Pinzer T., Hobohm C., Meixensberger J., Hacke W.; DESTINY II Investigators. Hemicraniectomy in older patients with extensive middle-cerebral-artery stroke. $N$ Engl J Med 2014; 370(12): 1091-1100, http://dx.doi.org/10.1056/ NEJMoa1311367.

58. Jüttler E., Bösel J., Amiri H., Schiller P., Limprecht R., Hacke W., Unterberg A.; DESTINY II Study Group. DESTINY II: decompressive surgery for the treatment of malignant infarction of the middle cerebral artery II. Int J Stroke 2011; 6(1): 79-86, http://dx.doi.org/10.1111/j.1747-4949.2010.00544.x.

59. Raffiq M.A., Haspani M.S., Kandasamy R., Abdullah J.M. Decompressive craniectomy for malignant middle cerebral artery infarction: impact on mortality and functional outcome. Surg Neurol Int 2014; 5: 102, http://dx.doi. org/10.4103/2152-7806.135342.

60. Schwab S., Steiner T., Aschoff A., Schwarz S., Steiner H.H., Jansen O., Hacke W. Early hemicraniectomy in patients with complete middle cerebral artery infarction. Stroke 1998; 29(9): 1888-1893, http://dx.doi.org/10.1161/01. str.29.9.1888.

61. Cho D.Y., Chen T.C., Lee H.C. Ultra-early decompressive craniectomy for malignant middle cerebral artery infarction. Surg Neurol 2003; 60(3): 227-233, http:// dx.doi.org/10.1016/s0090-3019(03)00266-0.

62. Sakai K., Iwahashi K., Terada K., Gohda Y., Sakurai M., Matsumoto Y. Outcome after external decompression for massive cerebral infarction. Med Chir (Tokyo) 1998; 38(3): 131-136, http://dx.doi.org/10.2176/nmc.38.131.

63. Doerfler A., Forsting M., Reith W., Staff C., Heiland S., Schäbitz W.R., von Kummer R., Hacke W., Sartor K. Decompressive craniectomy in a rat model of "malignant" cerebral hemispheric stroke: experimental support for an aggressive therapeutic approach. J Neurosurg 1996; 85(5): 853-859, http://dx.doi.org/10.3171/jns.1996.85.5.0853.

64. Engelhorn T., Dörfler A., Egelhof T., Schwab S., Heiland S., Sartor K., Forsting M. Follow-up monitoring with magnetic resonance tomography after decompressive trephining in experimental "malignant" hemispheric infarct. Zentralb/ Neurochir 1998; 59(3): 157-165.

65. Engelhorn T., Doerfler A., Kastrup A., Beaulieu C., 
de Crespigny A., Forsting M., Moseley M.E., Faraci F.M. Decompressive craniectomy, reperfusion, or a combination for early treatment of acute "malignant" cerebral hemispheric stroke in rats? Potential mechanisms studied by MRI. Stroke 1999; 30(7): 1456-1463, http://dx.doi.org/10.1161/01.str.30.7.1456.

66. Doerfler A., Schwab S., Hoffmann T.T., Engelhorn T., Forsting M. Combination of decompressive craniectomy and mild hypothermia ameliorates infarction volume after permanent focal ischemia in rats. Stroke 2001; 32(11): 26752681, http://dx.doi.org/10.1161/hs1101.098369.

67. Uhl E., Kreth F.W., Elias B., Goldammer A., Hempelmann R.G., Liefner M., Nowak G., Oertel M., Schmieder K., Schneider G.H. Outcome and prognostic factors of hemicraniectomy for space occupying cerebral infarction. J Neurol Neurosurg Psychiatry 2004; 75(2): 270-274.

68. Amorim R.L., de Andrade A.F., Gattás G.S., Paiva W.S., Menezes M., Teixeira M.J., Bor-Seng-Shu E. Improved hemodynamic parameters in middle cerebral artery infarction after decompressive craniectomy. Stroke 2014; 45(5): 13751380, http://dx.doi.org/10.1161/STROKEAHA.113.003670.

69. Shao A., Guo S., Chen S., Sun C., Wu H., Hong Y., Zhang J. Comparison between routine and improved decompressive craniectomy on patients with malignant cerebral artery infarction without traumatic brain injury. J Craniofac Surg 2013; 24(6): 2085-2088, http://dx.doi. org/10.1097/SCS.0b013e3182a2435a.

70. Shah S., Murthy S.B., Whitehead W.E., Jea A., Nassif L.M. Decompressive hemicraniectomy in pediatric patients with malignant middle cerebral artery infarction: case series and review of the literature. World Neurosurg 2013; 80(1-2): 126-133, http://dx.doi.org/10.1016/j. wneu.2013.06.001.

71. Bhattacharya P., Kansara A., Chaturvedi S., Coplin W. What drives the increasing utilisation of hemicraniectomy in acute ischaemic stroke? J Neurol Neurosurg Psychiatry 2013; 84(7): 727-731, http://dx.doi.org/10.1136/jnnp-2012-303610.

72. Neugebauer H., Heuschmann P.U., Jüttler $E$. Decompressive surgery for the treatment of malignant infarction of the middle cerebral artery - registry (DESTINY-R): design and protocols. BMC Neurol 2012; 12: 115, http://dx.doi. org/10.1186/1471-2377-12-115.

73. Montgomery A.K., Maixner W.J., Wallace D., Wray A., Mackay M.T. Decompressive craniectomy in childhood posterior circulation stroke: a case series and review of the literature. Pediatr Neurol 2012; 47(3): 193-197, http://dx.doi. org/10.1016/j.pediatrneurol.2012.05.005.

74. Kim H., Jin S.T., Kim Y.W., Kim S.R., Park I.S., Jo K.W. Predictors of malignant brain edema in middle cerebral artery infarction observed on CT angiography. J Clin Neurosci 2015; 22(3): 554-560, http://dx.doi.org/10.1016/j.jocn.2014.08.021.

75. Nikitin A.S., Burov S.A., Petrikov S.S., Asratyan S.A., Zavalishin E.E., Krylov V.V. Decompressive craniotomy at patients with malignant course of massive ischemic stroke. Neyrokhirurgiya 2014; 3: 23-29.

76. Agarwalla P.K., Stapleton C.J., Ogilvy C.S. Craniectomy in acute ischemic stroke. Neurosurgery 2014; 74(Suppl 1): S151-S162, http://dx.doi.org/10.1227/ NEU.0000000000000226.

77. Arnaout O.M., Aoun S.G., Batjer H.H., Bendok B.R. Decompressive hemicraniectomy after malignant middle cerebral artery infarction: rationale and controversies. Neurosurg Focus 2011; 30(6): E18, http://dx.doi.org/10.3171/2011.3.FOCUS1160.

78. Kelly A.G., Holloway R.G. Health state preferences and decision-making after malignant middle cerebral artery infarctions. Neurology 2010; 75(8): 682-687, http://dx.doi. org/10.1212/WNL.0b013e3181eee273.

79. Alshekhlee A., Horn C., Jung R., Alawi A.A., CruzFlores S. In-hospital mortality in acute ischemic stroke treated with hemicraniectomy in US hospitals. J Stroke Cerebrovasc Dis 2011; 20(3): 196-201, http://dx.doi.org/10.1016/j. jstrokecerebrovasdis.2009.11.019.

80. Nakagawa K., Bianchi M.T., Nakagawa S.S., Sorond F.A. Aggressive care after a massive stroke in young patients: is that what they want? Neurocrit Care 2010; 13(1): 118-122, http://dx.doi.org/10.1007/s12028-010-9340-7.

81. Allahtavakoli M., Kahnouei M.H., Rezazadeh $H$. , Roohbakhsh A., Mahmoodi M.H., Moghadam-Ahmadi A., Zarisfi M. Delayed combination therapy of local brain hypothermia and decompressive craniectomy on acute stroke outcome in rat. Iran J Basic Med Sci 2014; 17(7): 476-482.

82. Nikitin A.S., Asratyan S.A., Averin A.Yu., Kamchatnov P.R. Effective decompressive craniotomy in a young patient with massive ischemic stroke. Zhurnal nevrologii i psikhiatrii im. S.S. Korsakova 2013; 113(2): 12-26.

83. European Stroke Organisation (ESO) Executive Committee; ESO Writing Committee. Guidelines for management of ischaemic stroke and transient ischaemic attack 2008. Cerebrovasc Dis 2008; 25(5): 457-507, http:// dx.doi.org/10.1159/000131083.

84. Neugebauer H., Jüttler E. Hemicraniectomy for malignant middle cerebral artery infarction: current status and future directions. Int J Stroke 2014; 9(4): 460-467, http:// dx.doi.org/10.1111/ijs. 12211 .

85. Takeuchi S., Wada K., Nawashiro H., Arimoto H., Ohkawa H., Masaoka H., Otani N., Takasato Y. Decompressive craniectomy after intravenous tissue plasminogen activator administration for stroke. Clin Neurol Neurosurg 2012; 114(10): 1312-135, http://dx.doi.org/10.1016/j.clineuro.2012.03.044.

86. Wagner S., Schnippering H., Aschoff A., Koziol J.A., Schwab S., Steiner T. Suboptimum hemicraniectomy as a cause of additional cerebral lesions in patients with malignant infarction of the middle cerebral artery. J Neurosurg 2001; 94(5): 693-696, http://dx.doi.org/10.3171/jns.2001.94.5.0693.

87. Chung J., Bang O.Y., Lim Y.C., Park S.K., Shin Y.S. Newly suggested surgical method of decompressive craniectomy for patients with middle cerebral artery infarction. Neurologist 2011; 17(1): 11-15, http://dx.doi.org/10.1097/ NRL.0b013e3181f4ec88.

88. Demchuk A.M. Hemicraniectomy is a promising treatment in ischemic stroke. Can J Neurol Sci 2000; 27(4): 274-277, http://dx.doi.org/10.1017/s0317167100000986.

89. Zweckberger K., Juettler E., Bösel J., Unterberg W.A. Surgical aspects of decompression craniectomy in malignant stroke: review. Cerebrovasc Dis 2014; 38(5): 313-323, http:// dx.doi.org/10.1159/000365864.

90. Sobani Z.A., Shamim M.S., Zafar S.N., Qadeer M., Bilal N., Murtaza S.G., Enam S.A., Bari M.E. Cranioplasty after decompressive craniectomy: an institutional audit and analysis of factors related to complications. Surg Neurol Int 2011; 2(1): 123, http://dx.doi.org/10.4103/2152-7806.85055.

91. Wachter D., Reineke K., Behm T., Rohde V. Cranioplasty after decompressive hemicraniectomy: underestimated surgery-associated complications? Clin Neurol Neurosurg 2013; 115(8): 1293-1297, http://dx.doi. org/10.1016/j.clineuro.2012.12.002.

92. Rengachary S.S., Batnitzky S., Morantz R.A., 
Arjunan K., Jeffries B. Hemicraniectomy for acute massive cerebral infarction. Neurosurgery 1981; 8(3): 321-328, http:// dx.doi.org/10.1097/00006123-198103000-00004.

93. Vassileva E., Stoyanov P., Vavrek E., Stamenova P. Unexpected arterial recanalization after decompressive hemicraniectomy. J Stroke Cerebrovasc Dis 2013; 22(8): e661-e663, http://dx.doi.org/10.1016/j. jstrokecerebrovasdis.2013.05.023.

94. Pérez-Bárcena J., Goedhart P., Ibáñez J., Brell M., García R., Llinás P., Jiménez C., Ince C. Direct observation of human microcirculation during decompressive craniectomy after stroke. Crit Care Med 2011; 39(5): 1126-1129, http:// dx.doi.org/10.1097/CCM.0b013e31820ead5e.

95. Woitzik J., Hecht N., Pinczolits A., Sandow N., Major S., Winkler M.K., Weber-Carstens S., Dohmen C., Graf R., Strong A.J., Dreier J.P., Vajkoczy P.; COSBID study group. Propagation of cortical spreading depolarization in the human cortex after malignant stroke. Neurology 2013; 80(12): 10951102, http://dx.doi.org/10.1212/WNL.0b013e3182886932.

96. Smith E.R., Carter B.S., Ogilvy C.S. Proposed use of prophylactic decompressive craniectomy in poor-grade aneurysmal subarachnoid hemorrhage patients presenting with associated large sylvian hematomas. Neurosurgery 2002; 51(1): 117-124, http://dx.doi.org/10.1097/00006123200207000-00018.

97. Poca M.A., Benejam B., Sahuquillo J., Riveiro M., Frascheri L., Merino M.A., Delgado P., Alvarez-Sabin J. Monitoring intracranial pressure in patients with malignant middle cerebral artery infarction: is it useful? J Neurosurg 2010; 112(3): 648-657, http://dx.doi.org/10.3171/2009.7.JNS081677.

98. Arch A.E., Sheth K.N. Malignant cerebral edema after large anterior circulation infarction: a review. Curr Treat Options Cardiovasc Med 2014; 16(1): 275, http://dx.doi.org/10.1007/ s11936-013-0275-0.

99. Tihomirov S.E., Tzibusov S.N., Kravetz L.Ya. Using of the material "Reperen" ${ }^{\circledR}$ for plastics of defect of skull fornix (experimental and clinical results). Sibirskiy meditsinskiy zhurnal (Irkutsk) 2010; 2(93): 121-124.

100. Krylov V.V., Nikitin A.S., Dash'yan V.G., Burov S.A., Petrikov S.S., Asratyan S.A. Khirurgiya massivnogo ishemicheskogo insul'ta [Surgery of a massive ischemic stroke]. Moscow: GEOTAR-Media; 2016; 136 p. 